\title{
Den rettslige betydningen av yrkesetiske regler med utgangspunkt i lovfestede spesielle god skikk-regler
}

\author{
Borge Aadland \\ Institutt for byggfag, Høgskolen i Bergen, borge.aadland@hib.no
}

Med hjemmel i de lovfestede spesielle god skikk-reglene (SGS) har flere yrker utformet yrkesetiske regler med en lovmessig forankring. Denne artikkelen tar utgangspunkt i fem yrker og gir en juridisk analyse av god revisorskikk, god advokatskikk, god regnskapsføringsskikk, god meglerskikk og god landmålerskikk. Formålet er å sammenligne den rettslige betydningen av disse SGS-reglene. De sammenlignes ut fra hjemmelsgrunnlaget og hvilken bransjeorganisasjon som har utformet de yrkesetiske reglene, autorisasjonsordning og en hypotese om at de yrkesetiske reglene inneholder følgende elementer: profesjonsansvar, integritet, objektivitet, taushetsplikt og kompetansekrav.

Sammenligningen viser at lovfestede SGS-regler har ført til at de aktuelle bransjeorganisasjonene har tatt ansvar for å utforme de yrkesetiske reglene. Når det gjelder autorisasjonsordningen, har Finanstilsynet ansvaret for autorisasjonene til revisorer, regnskapsførere og eiendomsmeglere. For advokater har Tilsynsrådet for advokatvirksomhet ansvaret for å føre tilsyn med advokatbevillingene, mens landmålerne ikke er underlagt en autorisasjonsordning.

Analysen viser at en finner de fem elementene både i god revisorskikk, god advokatskikk, god regnskapsføringsskikk og god landmålerskikk. God meglerskikk er derimot svoert forskjellig fra de andre yrkesetiske reglene. Samlet viser analysene at de yrkesetiske reglene har en viss rettslig betydning, selv om den varierer.

Nøkkelord: lovfestede god skikk-regler, yrkesetiske regler

English summary: The significance of ethical rules based on legislated rules for Code of Conduct

In accordance with statutory authority rules for Code of conduct (CoC), several professions have designed ethical rules with a legal foundation. This article is based on a legal analysis of CoC for auditors, lawyers, accountants, real estate agents and for land surveyors. The purpose of the article is to compare the legal significance of these rules for the CoC. The various rules for CoC are compared in terms of their legal basis, the professional organisation which has designed the professional ethical rules and the system of authorisation. The rules for $\mathrm{CoC}$ are also compared in a hypothesis about five elements. The hypothesis is that the ethical rules contain the following elements: professionalism, integrity, objectivity, confidentiality and competency. 
The comparison shows that legislated rules for CoC have enabled the relevant professional organisations to take responsibility for designing professional ethical rules. In the case of system of authorisation, the "Financial Supervisory Authority of Norway» is responsible for authorising auditors, accountants and real estate agents. For lawyers the «Supervisory Council For Legal Practice» is responsible for supervising their authorisation, whereas land surveyors are not subject to an authorisation system - either public or professional.

The analysis shows that one can find all five elements in the CoC for auditors, lawyers, accountants, and land surveyors. The CoC for real estate agents, however, is different from the other ethical rules. Overall, the analysis shows that the ethical rules have a certain legal significance, although it varies.

Keywords: Legislated Code of conduct, Code of ethics

\section{Innledning}

De fleste lovfestede spesielle god skikk-reglene (SGS) kan forenklet beskrives som minimumskrav til kvalitet i yrkesutøvelsen utover øvrige lovbestemte krav. SGS-reglene skiller seg fra generelle god skikk-regler, som god forretningsskikk, ved at det er knyttet til utøvelsen av et bestemt yrke eller fagfelt. Med hjemmel i de lovfestede SGS-reglene har flere yrker i tillegg utformet yrkesetiske regler med en lovmessig forankring. I enkelte tilfeller vil de yrkesetiske reglene utgjøre hoveddelen av god skikk-regelen. Et typisk eksempel på dette er god advokatskikk som er utarbeidet av Den Norske Advokatforeningen.

Finanskrisen i 2008, saker knyttet til varsling i arbeidslivet og ulike korrupsjonsskandaler har vist at temaet er både viktig og samfunnsaktuelt. Det foreligger omfattende forskning på yrkesetikk - særlig om arbeidslivsforskning, helsepersonell og økonomi og det er flere internasjonale tidsskrifter med disse spesialfeltene som tema. Når det gjelder det særnorske fenomenet «lovfestede SGS-regler», er etikk kun kort omtalt i lærebøker. Formålet med denne artikkelen er å se nærmere på hvilken rettslig betydning de lovfestede SGS-reglene har. I tillegg vil en se nærmere på hva som kjennetegner de lovfestede SGS-reglene.

En gjennomgang av den rettslige betydningen av lovfestede SGS-regler vil omfatte både yrkesetiske regler som håndheves gjennom domstolene, og selvdømmeordninger som har en lovmessig forankring.

\section{Metodisk tilnærming}

Metodisk tar artikkelen utgangspunkt i en juridisk analyse av de lovfestede SGS-reglene, med særlig vekt på rettspraksis i tilknytning til disse. I presentasjonen av de lovfestede SGS-reglene vil hvert kapittel bli inndelt i hjemmelsgrunnlaget og hvilken bransjeorganisasjon som har utformet de yrkesetiske reglene, autorisasjonsordning og en hypotese om fem elementer. Enkelte av de nå lovfestede SGS-reglene har gjennom lovfestingen fått en kodifisering av eldre praksis, slik som god advokatskikk. 
God landmålerskikk, som ble lovfestet da matrikkelloven ${ }^{1}$ trådte i kraft 1 . januar 2010, har derimot verken eldre praksis eller rettspraksis å vise til. Det er derfor av særlig interesse å se nærmere på hvordan lovfestingen av SGS-regler er påvirket av andre lovfestede SGS-regler. Bergsåker (2008: 206) uttaler i den sammenheng at «likheter og ulikheter kan ha betydning for den inspirasjon og de impulser som kan hentes fra den ene god skikk-regelen til den andre».

I denne artikkelen analyseres først god revisorskikk, god advokatskikk, god regnskapsføringsskikk og god meglerskikk. Deretter vil en se på de nå lovfestede reglene om god landmålerskikk. At disse fire SGS-reglene og god landmålerskikk utgjør utvalget, skyldes at de representerer yrkesgrupper av en viss størrelse som har lovfestede SGSregler. Andre lovfestede SGS-regler som for eksempel god dommerskikk og god inkassoskikk er således valgt bort som følge av at de omfatter mindre yrkesgrupper. Det må imidlertid presiseres at god revisorskikk ikke er lovfestet, men er utledet fra det lovfestede begrepet god revisjonsskikk. Ved å analysere disse fire SGS-reglene vil en få frem variasjon og fellestrekk for yrkesetiske regler med hensyn til hvilken rettslig betydning de har. Det vil også kunne gi et godt grunnlag for å analysere betydningen av lovfestede SGSregler om etikk.

Innenfor fagfeltet etikk er det gjort svært mange forskjellige analyser av yrkesetiske regler. Når en i denne artikkelen metodisk tar utgangspunkt i en juridisk analyse, vil et begrenset rettskildemateriale være en metodisk utfordring. Det er derfor hensiktsmessig å sammenligne de ulike SGS-reglene med utgangspunkt i en hypotese om at de inneholder følgende fem elementer:

I Profesjonsansvar (profesjonell adferd) ${ }^{2}$

II Integritet

III Objektivitet (uavhengighet)

IV Taushetsplikt (fortrolighet)

V Kompetansekrav

Denne hypotesen tar utgangspunkt i den tradisjonelle oppbygningen som eldre yrkesetiske regler har hatt. Selv om bruk av hypoteser er mer vanlig i tradisjonelle samfunnsvitenskapelige metoder, så vil dette styrke den juridiske analysen i artikkelen.

For analysen er det naturlig å vise til hvordan Ims (2001: 341) ser på formålet med de yrkesetiske reglene:

Det å utvikle og reflektere over etiske retningslinjer (også kalt etisk kodeks, standarder, moralske regler eller hustavler), kan hjelpe oss til å skjerpe vår oppmerksomhet, klargjøre våre verdier og informere kunder/klienter/brukere om vårt profesjonelle ansvar. 


\section{En kort samlet redegjorelse for de ulovfestede reglene}

I denne artikkelen vil jeg ikke gi en grundig behandling av de ikke-lovfestede SGSreglene, som for eksempel etiske regler for god journalistikk. At slike regler kan ha rettslig betydning, fremgår gjennom omfattende rettspraksis for de ordinære domstolene. Bakgrunnen for å ikke inkludere slike ulovfestede SGS-regler i denne artikkelen er at selvdømmeordningene i slike tilfeller ikke har en lovmessig forankring. Det innebærer at enkeltavgjørelser og enkeltuttalelser fra selvdømmeordninger, som Pressens Faglige Utvalg (PFU), ikke er bindende for de ordinære domstolene. I konkrete saker innebærer det at en kan bli dømt i PFU, men frikjent i de ordinære domstolene - og motsatt. Det må likevel presiseres at det tradisjonelle utgangspunktet i norsk rettskildelære er at en god, ensartet praksis fra slike selvdømmeordninger, som er fulgt av yrkesutøverne over tid i den tro at det er en rettsregel, kan betraktes som sedvane som er bindende for domstolene.

Rettspraksis viser at domstolene i begrenset grad har drøftet det konkrete innholdet og betydningen av de ulovfestede SGS-reglene. Eksempelvis kan en vise til den korte henvisningen til de etiske reglene for Rådgivende Ingeniørers Forening (RIF) i dommen i skattesaken LA-1995-311. Et annet illustrerende eksempel er en dom fra LG-2009149105 , hvor domstolene viser til at det må stilles strenge krav til faglig etikk for privatetterforskere, uten at det er vist til Etiske retningslinjer for Norsk forening for etterforsking og sikkerhet (NFES).

Yrkesetiske regler for ulike grupper av helsepersonell har gjennom administrativ praksis blitt tillagt vekt i vurderingen om advarsel, begrenset autorisasjon og tilbakekall av autorisasjon. Det er relativt få saker som er brakt inn for domstolene, og behandlet for lagmannsretten eller høyesterett. I dommene LB-1997-1959 og LA-2002-1117, som gjaldt tilbakekall av autorisasjon som lege, og dommen RG 1997 s. 398 (Borgarting), som gjaldt tilbakekall av psykologs godkjenning, er ikke de yrkesetiske reglene nærmere behandlet, selv om det er vist etikk i dommen.

Det finnes likevel eksempler i rettspraksis på at Legeforeningens etiske regler er lagt til grunn. Eksempelvis var Legeforeningens etiske regler $\$ 13$ om legers alminnelige informasjonsplikt et tolkningsmoment i dommen fra Rt. 1977 s. 1035, som fastslo pasienters rett til innsyn i egen sykejournal. Et annet eksempel fremgår av dommen i RG $1984 \mathrm{s.} 942$ (Eidsivating), hvor flertallet på to dommere la til grunn at de etiske reglene for leger del II $\$ 17$ var et sentralt tolkningsmoment for innholdet av en avtale mellom to leger.

\section{Rettslige standarder og SGS-reglene}

SGS-reglene er behandlet i rettskildelærelitteraturen av Boe (1996), Eckhoff/Helgesen (1997), Fleicher (1998) og Nygaard (2004), samt av Gomard (1997) og Lunde (2001). Disse er nærmere analysert i Aadland (2012) når det gjelder vektlegging av bransjepraksis som målestokk for utøvelsen av yrket. Når en i denne artikkelen tar utgangspunkt i de yrkesetiske reglene, er det nærliggende å fremheve utgangspunktet til Nygaard (2004: 190-191) om at en SGS-regel er en rettslig standard som er målestokk eller mønster for sosialt korrekt fremferd. Ved å lovfeste SGS-regler blir disse målestokkene fra det praktiske liv rettsregler 
(Nygaard 2004: 191 jf. 253-254). Forutsetningen for at målestokken blir en rettsregel, er at «[s]kikken må vera god» (Nygaard 2004: 191).

Det er i dag ikke tvil om at lovfestede SGS-regler gjelder for alle yrkesutøvere innenfor det aktuelle yrket, selv om en nedenfor under god advokatskikk skal se at dette ikke var tilfelle tidligere. Dette kan en utlede fra Nygaard (2004: 191), som viser til at domstolene må ta standpunkt til en SGS-regel selv om det ikke er påvist noen skikk på området eller skikken er lite dokumentert, slik som i dommen Rt. 1984 s. 248. Denne dommen er analysert nærmere av Nygaard (2004: 217), som fremhever at det stilles et strengt krav til relevans mellom de utsagnene som et organ avgir og den konkrete saken. Relevanskravet og kravet om at skikken må være god, er således avgjørende for at reglene om etikk er bindende.

Kretsen av de personene som kan påberope seg de lovfestede yrkesetiske SGS-reglene, er i utgangspunktet ikke begrenset gjennom SGS-reglene i seg selv. Retten til å anlegge søksmål er derimot begrenset ved at tvisteloven ${ }^{3} \$ 1-3$ andre ledd oppstiller krav om partenes tilknytning til tvistegjenstanden. Det innebærer at saksøkeren må ha en beskyttelsesverdig interesse i å få dom i saken.

\section{God revisorskikk}

\section{Hjemmel og bransjeorgansiasjon}

God revisorskikk er som sagt ikke lovfestet, men er utledet fra god revisjonsskikk som fremgår av jf. $\$ 5-2$ andre ledd i revisorloven. God revisorskikk er utarbeidet av Den norske Revisorforening (DnR), med utgangspunkt i en oversettelse av «Code of Ethics» fra International Federation of Accountants (IFAC). DnR har i oversettelsen gjort språklige forenklinger og tilpasninger til den norske lovgivningen. Med hensyn til denne artikkelens problemstilling er det bare del A om «Generelle regler for alle revisorer» en vil se nærmere på. Denne delen gjelder for alle medlemmer av DnR, men vil ut fra relevanskravet til Nygaard (2004: 217) også bli lagt til grunn for revisorer som ikke er medlemmer.

\section{Autorisasjonsordning}

Finanstilsynet (tidligere kalt Kredittilsynet) har ansvaret for å godkjenne registrerte og autoriserte revisorer, jf. revisorloven ${ }^{4} \S 3-1$. At det offentlige på denne måten har ansvaret for godkjenningsordningen, innebærer at det blir en klar ansvarsfordeling mellom det offentlige og bransjen. Revisorbransjens ansvar for å utvikle god revisorskikk og god revisjonsskikk blir på denne måten indirekte underlagt en forvaltningskontroll når Finanstilsynet i tråd med revisorlovens $\$ 9-1$ skal føre tilsyn/kontroll med revisorene og revisjonsbransjen. 


\section{Hypotesen}

En kan klart fastslå at reglene fra DnR bygger på de fem elementene i kap 100.4 som har fått overskriften «Grunnleggende prinsipper»:
a. Integritet
b. Objektivitet
c. Faglig kompetanse og tilbørlig aktsomhet
d. Konfidensialitet
e. Profesjonell adferd

Ettersom reglene i utgangspunktet er en oversettelse fra IFAC, ser en tydelig den internasjonale tradisjonen, hvor de generelle prinsippene mer eller mindre ordrett gjentas ulike steder. Ut fra den norske oversettelsen, som er tilpasset norsk lovgivning, er det vanskelig å se hvorfor en har valgt å opprettholde denne dobbeltbehandlingen. Detaljerte regler gir i realiteten liten veiledning, og selv om de ikke er ment å være uttømmende, kan de virke begrensende ut fra intensjonen om at reglene skal fungere som et prinsippbasert rammeverk, jf. kap. 100.5-100.8.

Slik revisorloven fremstår i dag, har en etter lovendringen som trådte i kraft 1. juni 2009, fătt et klart innslag av etikk i loven. Særlig siste lovendring, hvor det kom inn en ny $\$ 1-2$ om revisors rolle, viser dette:

Revisor er allmennhetens tillitsperson ved utøvelse av virksomhet som nevnt i $\$ 1-1$ annet ledd. Revisor skal utøve sin virksomhet med integritet, objektivitet og aktsomhet.

Revisorloven har derfor nå regler både om integritet ( $\$ 1-2)$, objektivitet $(\$ 4-1)$, kompetansekrav ( $\$ 3-2$ ) og taushetsplikt ( $\$ 6-1)$. Loven mangler imidlertid, på samme måte som den nye eiendomsmeglerloven, regler om profesjonsansvar, angitt som profesjonell adferd $\mathrm{i}$ «Regler om etikk».

Det særegne med reglene fra DnR er at en gjennom reglene ønsker å bevisstgjøre revisorene på aktuelle trusler og forholdsregler gjennom kap. 100.10-100.15. I tillegg blir det i kap. 100.16-100.21 lagt vekt på løsning av etiske konflikter. Det er således nærliggende å tolke det slik at DnR fremhever selvrefleksjon gjennom aktiv dannelse av personlig holdning.

Domstolenes generelle prøvelsesrett i forbindelse med SGS-regler kan ifølge Nygaard (2004: 191) utledes av det at «[s]kikken må vera god». Gjennom domstolskontrollen etterprøves rettsregelens kvalitative innhold, slik som dommen i Rt. 1998 s. 1315, som gjaldt god forretningsskikk. Domstolenes prøvelsesrett av rettsregelen god revisorskikk fremgår av dommen fra RG 1997 s. 1594 (Borgarting), hvor det prinsipielt er uttalt at:

\footnotetext{
Saken gjelder spørsmålet om vedtaket i Kredittilsynets styre om å inndra As revisorbevilling for 2 år i medhold av revisorloven $\$ 14$ tredje ledd, er gyldig. Partene er enige om at lagmannsretten kan prøve alle sider av dette forvaltningsskjønnet, også subsumsjonsskjønnet, jf Ot.prp.nr. 41 (1963-64) Om lov om revisjon og revisorer, side 27-28. Lagmannsretten tar utgangspunkt $i$ at det skal vises tilbakeholdenhet med å overprøve Kredittilsynets skjønnsmessige avgjørelse av om A 'må anses uskikket som revisor', og reaksjonsformen, jf Høyesteretts dommer i Rt-1975-603, Rt-1991-586 og Rt1995-1427.
} 
Det er således full prøvelsesrett for domstolene i saker om inndragning av revisorbevilling, men domstolene har begrenset adgang til å etterprøve Finanstilsynets vurdering om revisor er uskikket, samt reaksjonsformen fra Finanstilsynet. Reglene om etikk sier dommen derimot lite om.

\section{God advokatskikk}

\section{Hjemmel og bransjeorganisasjon}

Hjemmelen for god advokatskikk fremgår i dag av domstolloven ${ }^{5} \$ 224$. Lovgiver har her presisert i $\S 224$ første ledd andre punktum at «det hører til kravet om god advokatskikk blant annet at advokatvirksomhet skal utøves grundig, samvittighetsfullt og i overensstemmelse med hva berettigede hensyn til klientens tarv tilsier, og at oppdraget skal utføres tilstrekkelig hurtig».

I Ot.prp. nr. 39 (1994-1995) er det i merknadene til de enkelte paragrafene fremhevet at $\$ 224$ første ledd andre punktum ikke er uttømmende. Tvert imot har Den Norske Advokatforening i $\$ 224$ andre ledd fått hjemmel til «å utarbeide nærmere regler for hva som anses som god advokatskikk». Disse reglene for god advokatskikk er samlet i advokatforskriften $^{6}$ kap. 12, og har virkning som forskrift jf. $\$ 224$ andre ledd andre punktum. God advokatskikk er kjernen i det som er rammelovgivningen for advokatretten, hvor detaljlovgivningen fremgår av forskriften.

Det er Den Norske Advokatforeningen som har i oppgave å utforme reglene for god advokatskikk (reglene stadfestes av Kongen). Dette er i Ot.prp. nr. 39 (1994-1995: 14) begrunnet ut fra at «reglene skal kunne håndheves overfor alle advokater». Utgangspunktet for denne begrunnelsen var at Norges Juristforbund i forbindelse med Ot.prp. nr. 7 (1990-1991: 62) hadde følgende kommentar om den tidligere rettilstanden:

Flere av de problemstillinger som er nevnt foran, er omhandlet i Advokatforeningens regler for god advokatskikk, men disse har ikke lovskarakter, og gjelder heller ikke for advokater som ikke er medlem av Advokatforeningen.

NOU (2002:18: 61) viser til at «[r] eglene for god advokatskikk har siden stiftelsen i 1908 vært utarbeidet av Advokatforeningen som selvpålagt bransjeregulering». Reglene har flere ganger vært revidert, blant annet var det omfattende revisjoner i 1967 og 1991.

En dom som kan være av prinsipiell interesse med hensyn til den historiske utviklingen av god advokatskikk, er Rt. 1998 s. 1306. Selve problemstillingen i dommen var om en advokat hadde rett til å avregne honorar og utlegg i innestående på klientkonto. I forbindelse med denne artikkelen er det sentralt at motregningen ble gjennomført i 1990. På dette tidspunktet var ikke god advokatskikk nedfelt i domstolloven. På side 1311-1312 tok Høyesterett utgangspunkt $i$ at advokatforskriften fra 20. desember 1996 videreførte de tidligere bestemmelsene om avregning av advokaters tilgodehavende i klientmidler, nedfelt gjennom forskrift av 1. desember $1975 \mathrm{nr}$. 1 om advokaters regnskapsførsel. Det var dermed ikke et problem at Regler for god advokatskikk fra 1967 ikke inneholdt slike 
bestemmelser, når en kunne tolke dette ut fra flere av Disiplinærnemndas beslutninger fra 1990-1991. Disse beslutningene førte også til at Den Norske Advokatforening 14. juni 1991 vedtok at en i tråd med reglene for god advokatskikk kan ta dekning for sitt tilgodehavende i klientmidler «med mindre annet er avtalt eller forutsatt».

Høyesterett la dermed til grunn at god advokatskikk ikke er et «nytt» begrep eller prinsipp som har medført nye krav i forbindelse med tilføyelsene i domstolloven i 1995. Høyesterett la også vekt på praksis nedfelt gjennom Disiplinærnemndas beslutninger.

\section{Autorisasjonsordning}

Tilsynsrådet for advokatvirksomhet har ansvaret for å utstede autorisasjon som advokatfullmektig og advokatbevilling, jf. domstolloven $\$ 220$. Ifølge Den Norske Advokatforeningen er det i praksis Advokatbevillingsnemnden som treffer vedtak etter forslag fra Tilsynsrådet for advokatvirksomhet og Disiplinærnemnden i saker om tilbakekalling eller suspensjon av advokatbevillinger, rett til å yte rettshjelp på spesielle rettsområder mv. Sammen med advokatforskriften kap. 8 er domstolloven $\S 220$ også hjemmelen til kompetansekravet. I tillegg har Advokatforeningen satt krav om 80 timer obligatorisk etterutdanning, hvorav minimum fem timer etikk, for sine medlemmer i løpet av en femårsperiode, jf. \$12-1 i Advokatforeningens vedtekter.

I en kjennelse fra Høyesteretts kjæremålsutvalg Rt. 2000 s. 536 er spørsmålet om god advokatskikk dynamiske karakter vurdert:

Reglene [advokatforskriften] utvikles på grunnlag av den til enhver tid herskende oppfatning blant ansvarsbevisste utøvere av advokatyrket og håndheves av Advokatforeningens regionale disiplinærutvalg og Disiplinærnemnden, se domstolloven $\$ 227$, jf. advokatforskriften kap. 5, jf. kap. 12 pkt. 1.1. (side 542)

Høyesteretts kjæremålsutvalg forutsetter her at god advokatskikk skal være et dynamisk begrep som må gjenspeiles i en tilsvarende dynamisk utvikling av advokatforskriften. Når Haraldsen (2008: 9) fremhever at det foreligger «i meget begrenset utstrekning forarbeider» til advokatforskriften, så konkluderes det med at «sikkert er det imidlertid at de skrevne regler ikke er uttømmende». Når de skrevne regler suppleres med uskrevne regler, så ivaretas reglenes dynamiske funksjon.

\section{Hypotesen}

Av de fem elementene fra den innledende hypotesen finner en fire av disse i advokatforskriften kap. 12.

1.3 Advokaters opptreden

2.1 Uavhengighet

2.2 Tillitsforhold

2.3 Fortrolighet 
Når det gjelder kompetansekravet, fremgår dette, som fremhevet ovenfor, gjennom autorisasjonsordningen. Indirekte har også kap. 12 i advokatforskriften en erkjennelse av advokatyrkets kompleksitet i pkt. 3.1.4 første ledd, hvor utgangspunktet er:

En advokat bør ikke påta seg et oppdrag når han vet eller bør vite at han mangler den nødvendige kompetanse dersom han ikke kan samrå seg med en kvalifisert kollega.

I advokatforskriften pkt. 2.2 fremgår det at advokaten i sin virksomhet er «avhengig av tillit som bare kan oppnås når advokatens hederlig og integritet er hevet over tvil». Det er naturlig å se integritet i sammenheng med advokatforskriftens pkt. 1.3 andre punktum om profesjonsansvar. Her fremgår det at «advokaten må unngå en opptreden som er egnet til å skade standens og yrkets anseelse». Av ordlyden fremgår det at advokatforskriften, på samme måte som reglene om etikk for revisorer, formulerer reglene om profesjonsansvar som en regel om hva en skal unngå.

Objektivitet er i advokatforskriften beskrevet i pkt. 2.1 som et uavhengighetsprinsipp, og taushetsplikten er i pkt. 2.3 beskrevet som et fortrolighetsprinsipp. Foruten forskjellen i ordlyden, samt at disse to punktene har fått en relativt utfyllende beskrivelse i advokatforskriften, er det ikke noe særegent ved dem.

Når det gjelder domstolskontrollen med god advokatskikk, fremgår det av en kjennelse fra Høyesteretts Kjæremålsutvalg Rt. 2000 s. 1948 at:

Etter kjæremålsutvalgets oppfatning må disse reglene [advokatforskriftens pkt. 3.2.1, 3.2.3 og 3.2.4] anses som yrkesetiske regler som ikke kan håndheves av domstolene. Det at disse reglene etter domstolloven $\$ 224$ annet ledd annet punktum har 'virkning som forskrift', betyr bare at reglene ikke bare er bindende for medlemmer av Advokatforeningen, men for alle advokater. Reglene håndheves av Advokatforeningens regionale disiplinærutvalg og Disiplinærnemnden, se domstolloven $\$ 227$, jf. advokatforskriften kap. 5, jf. kap. 12 pkt. 1.1. Gyldigheten av de vedtak som disse organene måtte treffe, kan i den utstrekning de må anses å gjelde rettigheter eller rettsforhold, prøves av domstolene, jf. tvistemålsloven $₫ 54$. (side 1952)

Selv om det i denne saken var en konkret vurdering av enkelte punkt i advokatforskriften, er det nærliggende å tolke det slik at Høyesterett vil legge til grunn tilsvarende tolkning og argumentasjon når det gjelder håndhevelse av andre punkter i advokatforskriften.

Videre er det i Rt. 2000 s.1948 fremhevet at:

Den kjærende part har som begrunnelse for at domstolene må kunne prøve innholdet av reglene om god advokatskikk, blant annet vist til Grunnloven $\$ 88$ og EMK artikkel $6 \mathrm{nr}$. 1. Det er imidlertid en forutsetning for at borgerne på grunnlag av Grunnloven eller EMK artikkel 6 nr. 1 kan gjøre krav på domstolsbehandling av rettigheter eller plikter, at det er tale om rettigheter eller plikter som bygger på nasjonale rettsregler. Verken Grunnloven eller EMK artikkel 6 nr. 1 gir krav på å få prøvd yrkesetiske regler for domstolene. (side 1952)

Prinsipielt innebærer dette at domstolene ikke har plikt til å prøve de yrkesetiske reglene for domstolene, uavhengig av hvilket yrke de er knyttet til. Det særegne med god advokatskikk er Advokatforeningens selvdømmeordninger, herunder foreningens regionale disiplinærutvalg og Disiplinærnemnden. Haraldsen (2008: 125) viser til at domstolenes 
overprøving av selvdømmeordningen er uklar, men at «det synes åpenbart at domstolene i noen utstrekning har slik kompetanse», og viser til Michelsen (1999: 347-348) ${ }^{7}$.

Med unntak av mindre begrensninger som eventuelt følger av selvdømmeordningen, er det vanskelig å se at domstolskontrollen med både god advokatskikk og advokatforskriften skulle være annerledes enn for andre etiske regler som er knyttet til autorisasjonsordninger. Dermed må det legges til grunn at domstolenes prøvelsesrett i utgangspunktet fremgår av de statsrettslige prinsippene, slik det blant annet fremgår av Andenæs (1998: 288). At domstolene vil vise tilbakeholdenhet med å overprøve Advokatforeningens regionale disiplinærutvalg og Disiplinærnemnden, vil derimot være en naturlig forståelse av dommen fra RG 1997 s. 1594 (Borgarting), som ble gjennomgått ovenfor i tilknytning til god revisorskikk. En annen viktig årsak til at domstolene vil vise en viss tilbakeholdenhet med å overprøve disse beslutningene, fremgår også av de statsrettslige prinsippene. Kombinasjonen av domstolskontroll og selvregulering er således i tråd med maktfordelingsprinsippet i Norge.

\section{God regnskapsforingsskikk}

\section{Hjemmel og bransjeorganisasjon}

Regnskapsstandardene fra Norsk RegnskapsStiftelse (NRS) er knyttet til god regnskapsskikk, men inneholder ikke regler om etikk. Reglene om etikk er derimot laget av Norges Autoriserte Regnskapsføreres Forening (NARF) gjennom «Etisk regelverk for autoriserte regnskapsførere». Årsaken til at det etiske regelverket er utarbeidet av NARF og ikke av NRS, er at de yrkesetiske reglene har sin hjemmel i god regnskapsføringsskikk og ikke i god regnskapsskikk.

NARF vedtok 18. april 2004 det etiske regelverket for autoriserte regnskapsførere som er medlemmer av NARF. Allerede høsten 2009 oppnevnte NARF et etisk utvalg for å gjennomgå og vurdere dette regelverket. Revisjonen av det etiske regelverket ble ferdigstilt ved utgangen av 2010, med høringsfrist 21. februar 2011, og det trådte i kraft 1. januar 2012. Styret i NARF la i mandatet til etisk utvalg vekt på at «formålet med arbeidet er å sikre at det etiske regelverket bidrar til at autoriserte regnskapsførere følger en yrkesholdning og foretar valg som fremmer den etiske standarden for yrket, samtidig som at etikk får tilstrekkelig oppmerksomhet i bransjen». I forordet til nytt etisk regelverk er det presisert at oppfyllelse av intensjonene i regelverket forutsetter at «den som er ansvarlig for virksomheten, sørger for en god intern prosess med implementering av regelverket, at det etableres gode interne rutiner i foretaket og etableres god intern kontroll med hensyn til måloppfyllelsen».

\section{Autorisasjonsordning}

God regnskapsføringsskikk ble lovfestet gjennom en endringslov av 1. juni 2006 knyttet til regnskapsførerloven ${ }^{8}$. Lovforslaget som kom fra Finanstilsynet, må sees i lys av at det 
er de som har ansvaret for å autorisere regnskapsførere, jf. $\$ 1$ første ledd i regnskapsførerloven. På samme måte som en har en klar ansvarsfordeling mellom Finanstilsynet og bransjen når det gjelder god revisorskikk, har en nå fått en tilsvarende ansvarsfordeling for god regnskapsføringsskikk. Videre er det i Ot.prp. nr. 44 (2005-2006: 10) lagt vekt på uttalelsen fra Finanstilsynet om at:

Det presiseres at referansen i loven vil gjelde god regnskapsføringsskikk, slik dette oppfattes av dyktige og samvittighetsfulle utøvere av yrket.

Med henvisningen til «dyktige og samvittighetsfulle utøvere av yrket» er det klart at en her har ment at denne rettslige standarden skal tolkes og forstås på samme måte som andre SGS-regler. Som en skal se nedenfor, har de etiske reglene for eiendomsmeglerne en lignende ordlyd. At det er et behov for å vie SGS-reglene stor oppmerksomhet, med hensyn til både faglig kvalitet og etikk, kan illustreres gjennom erkjennelsen fra Regnskapslovkomiteen av 1959 (avgitt 5. oktober 1962: 73) (om god regnskapsskikk).

Begrepet skikk forutsetter en fast forekommende praksis med en viss utbredelse. Derimot vil en god regnskapsskikk kanskje bare finnes hos en del av de regnskapspliktige.

Det skal likevel her presiseres at det ikke foreligger rettspraksis i tilknytning til god regnskapsføringsskikk eller tilbakekalling av autorisasjon etter regnskapsførerloven $₫ 7$. Dette tyder på at utøverne av yrket i stor grad følger og anerkjenner de bransjestandardene som er gitt av NARF, samt Finanstilsynets avgjørelser. Uten konkret rettspraksis må en også legge til grunn domstolenes alminnelige prøvelsesrett med hensyn til regelverket.

\section{Hypotesen}

Gjennom revisjonen av «Etisk regelverk» har en fått markert endring og utvidelse av regelverket. I det tidligere regelverket var det kun integritet i pkt. 2.2 som klart fremgikk med tanke på de fem elementene. Indirekte kunne det også gjennom pkt. 1.1 tolkes en henvisning til profesjonsansvaret. I det nye regelverket er det derimot en klar henvisning til fire av de fem elementene:

- Kapittel 2 - Integritet

- Kapittel 3 - Objektivitet

- Kapittel 4 - Profesjonalitet

- Kapittel 6 - Konfidensialitet

Kompetansekravet utgjør det femte elementet, og det fremgår av forskriften ${ }^{9}$ med hjemmel i regnskapsførerloven $₫ \$ 4$ og 5 . Det en særlig kan legge merke til, er at etterutdanningskravet i forskriften $₫ 4$-1 stiller krav til at autoriserte regnskapsførere til enhver tid skal kunne dokumentere at de $\mathrm{i}$ tre foregående kalenderår har etterutdanning på minst 14 timer fra regnskapsførerregelverket og god regnskapsføringsskikk.

Etisk Regelverk pkt. 1.1 innleder med: 
Målsettingen med det etiske regelverket er å medvirke til at autoriserte regnskapsførere (ARF) følger en yrkesholdning og foretar valg som fremmer den etiske standarden for yrket, samtidig som det skapes tillit og respekt hos kunder, offentlige myndigheter, finansinstitusjoner, forretningsforbindelser, kolleger og allmennheten for øvrig.

NARF bruker en positiv ordlyd når de sier at reglene skal «fremme den etiske standarden for yrket». At en her i pkt. 1.1 trekker frem yrkesholdning, viser at målsettingen for NARF er å skape etisk bevissthet. For å øke den etiske bevisstheten er det også gitt utfyllende tekst til Etisk Regelverk med eksempler på spørsmål og svar.

\section{God meglerskikk}

\section{Hjemmel og bransjeorganisasjon}

Hjemmelsgrunnlaget for god meglerskikk fremgår av eiendomsmeglingsloven ${ }^{10} \S 6-3$. Selv om en dermed har en lovmessig forankring for de etiske reglene fra Norges Eiendomsmeglerforbund (NEF), er de likevel svært forskjellig fra de øvrige reglene om etikk som er analysert ovenfor.

Historisk har de etiske reglene alltid vært under en viss utvikling. Det skyldes utviklingen av eiendomsmegleryrket i Norge, som har vært forskjellig fra EU-landene, med unntak av Sverige (jf. Bergsåker 2008: 95). Lovgivers syn på de etiske reglene kan illustreres med en henvisning til NOU (1987:14: 44):

Utvalget ser det slik at organisasjonenes etiske regler vil kunne være et supplement til lovgivning, rettspraksis og annen myndighetspraksis med tanke på den nærmere konkretisering av hva som følger av god meglerskikk.

Med utgangspunkt i dette er det ikke tvil om at de etiske reglene kan ha en viss rettslig betydning. At domstolene kan legge vekt på dem, fremgår av dommen i Rt. 1988 s. 7, hvor det ble fremhevet på s. 11 at:

Heller ikke fra reglementet for eiendomsmeglere som er gitt i medhold av loven, eller fra de etiske regler som meglernes yrkesorganisasjon har utferdiget, kan man trekke noen slik slutning.

Høyesterett kom i denne saken til at informasjonsplikten om de skattemessige konsekvensene verken kunne utledes av loven eller av de etiske reglene, slik det var prosedert fra en av partene. En har også eksempler fra rettspraksis hvor de etiske reglene har underbygget tolkningen av konkrete regler, som i dommen LG-1998-2283, hvor det fremgikk at: «Dette er neppe i samsvar med meglerloven $\$ 3-6 \mathrm{nr} .3$ og $\$ 3-7$, og synes åpenbart ikke i samsvar de krav som stilles i de etiske regler $\$ 5$ og $\$ 6$.»

Problemstillingen i NOU (1987:14: 44) handlet videre om hvorvidt de etiske reglene helt eller delvis skulle tas inn loven. Utvalget konkluderte med at en ikke så «det nødvendig å berøre bransjens etiske regler i lovgivningen». På samme måte ble det konkludert med at «[u]tvalget ser det ikke som noen naturlig oppgave for myndighetene å utarbeide 
egne etiske regler for eiendomsmegling ut over det som nedfeller seg i praksis vedrørende tilsynet med eiendomsmeglingen».

\section{Autorisasjonsordning}

Finanstilsynet har ansvaret for å utstede eiendomsmeglerbrev til de som oppfyller vilkårene i eiendomsmeglingsloven $\$ 4-2$ med forskrifter. I tillegg har Finanstilsynet ansvaret for å gi jurister tillatelse til å være fagansvarlig og ansvarlig megler i samsvar med eiendomsmeglingsloven $₫ 4$-3. Tilsynet med eiendomsmeglingen gjennomføres også av Finanstilsynet, som kan tilbakekalle eiendomsmeglerbrev og tillatelse til jurister i tråd med eiendomsmeglingsloven $\$ 8-1$, jf. $\$ \$ 8-4$ og 8-5. Den praksisen som utvikles gjennom tilsynsordningen, er en viktig korreksjon på de etiske reglene.

\section{Hypotesen}

Slik de gjeldende etiske reglene nå fremstår etter siste endring 7. mai 2010, har de i begrenset grad en henvisning til de fem elementene fra hypotesen i innledningen. Av $\$ 1$ i de etiske regler kan en likevel vise til følgende:

(Første punktum) Medlemmer av Norges Eiendomsmeglerforbund skal i sin virksomhet opptre korrekt, hederlig og i samsvar med god meglerskikk.

(Andre punktum) God meglerskikk er å utføre megleroppdrag i overensstemmelse med den oppfatning av etiske og faglige prinsipper som til enhver tid er alminnelig anerkjente og praktisert av dyktige og ansvarsbevisste utøvere av yrket.

Første punktum har en henvisning til integritet, og i andre punktum kan det utledes et krav om profesjonell adferd. Til sammenligning viser etiske regler som er utarbeidet fra andre SGS-regler, til en mer generell regel om profesjonell adferd, ved at en skal opptre på en slik måte at en ikke skader yrkets anseelse eller omdømme.

Tidligere hadde $₫ 1$ i de etiske reglene også en henvisning i tredje punktum til at: «Medlemmene skal i sin faglige virksomhet ha en fri og uavhengig stilling.» Dette er nå fjernet og erstattet med en henvisning i $\$ 4$ til eiendomsmeglingsloven kap. 5 om uavhengighet.

Formålet med rettslige standarder er at de skal være dynamiske, slik at de i tråd med Nygaard (2004: 190) følger «samfunnssynet på tida for den aktuelle handlinga». Selv om de etiske reglene fra NEF har vært under en viss utvikling, har NEF ikke klart å følge opp med en kontinuerlig utvikling. Det har medført at aktuelle etiske problemstillinger ikke til enhver tid har vært omtalt. Eksempelvis fremgår det av dommen fra RG 1991 s. 682:

Noen fast, entydig bransjepraksis foreligger ikke, men det er opplyst under ankeforhandlingen at egenhandel i spekulasjonshensikt ikke godtas under noen omstendighet, og at man ellers søker å opptre så varsomt som mulig. Eiendomsmeglerforbundets eget regelverk - de etiske regler - inneholder ingen særskilte bestemmelser om egenhandel, men ifølge forbundets direktør har man under overveielse å innta slike regler. 
Denne passive opptredenen fra NEF gjenspeiler mye av problemet for eiendomsmeglerbransjen, særlig med hensyn til etikk. Lovgiver har derfor i detalj regulert flere av elementene i de yrkesetiske reglene gjennom den nye eiendomsmeglingsloven. Dette blir særlig tydelig sammenlignet med den gamle eiendomsmeglingsloven ${ }^{11}$. Lovgiver har dermed endret synet fra NOU (1987: 14), hvor en ikke så det som nødvendig å ta bransjens etiske regler inn i lovgivningen. Den nye eiendomsmeglingsloven har for eksempel i $\$ 6-3$ første ledd andre punktum og $\$ 5-1$ vist til integritet. Når det gjelder kravet om objektivitet, fremgår dette av kap. 5 om uavhengighet. Kompetansekravet er nå også lovregulert med hensyn til etterutdanning gjennom $₫ 4-6$. Taushetsplikt har tradisjonelt vært regulert gjennom lovgivningen, og fremgår nå av $\$ 3-6$. På denne måten har de etiske reglene fra NEF mistet mye av sin selvstendige betydning når det gjelder de fem elementene. Ved at de etiske reglene i realiteten fremgår av den nye eiendomsmeglerloven, er det nærliggende å konkludere med at reglene har begrenset betydning.

\section{God landmålerskikk}

\section{Hjemmel og bransjeorganisasjon}

Ettersom god landmålerskikk er et nytt begrep som ble innført i matrikkelloven $₫ 33$, som trådte i kraft 1. januar 2010, har en verken eldre praksis eller rettspraksis å vise til. At god landmålerskikk skal inneholde yrkesetiske regler, fremgår av Ot.prp. nr. 70 (2004-2005: 79):

Det er viktig at naboar og andre partar som forretningane vedkjem kan ha tillit til landmålaren, både med omsyn til fagleg dugleik og yrkesetikk. ... Utvalet sammanfattar dette i eit krav om at landmålar skal utføre oppdraget i samsvar med «god landmålarskikk», jf. lovutkastet $₫ 38$ første ledd.

Norges Jordskiftekandidatforening (NJKF) vedtok på årsmøtet 25. oktober 2007 «Etiske retningslinjer for sertifiserte kandidater i Norges Jordskiftekandidatforening». Disse ble forenklet og revidert våren 2011. Når det gjelder den rettslige betydningen av disse etiske retningslinjene, er det flere problemstillinger som står sentralt. Vil domstolene legge vekt på dem? I hvilken sammenheng vil de kunne bli tillagt vekt, og hvordan vil domstolene vektlegge dem? De to siste problemstillingene vil bli kort drøftet $\mathrm{i}$ avslutningen, ettersom de i stor grad bygger på analysene av de øvrige yrkesetiske reglene.

Spørsmålet om hvorvidt domstolene vil legge vekt på de etiske retningslinjene, er særdeles relevant. På bakgrunn av at det ikke foreligger konkret rettspraksis hvor spørsmålet er behandlet, må en vurdere dette i lys av relevanskravet til Nygaard (2004: 217). Oppfyller NJKF dette relevanskravet? De gir følgende beskrivelse av seg selv:

Norges Jordskiftekandidatforening (NJKF) er en faglig gruppe av Teknisk-naturvitenskapelig forening (Tekna). De fleste medlemmene (ca 1050) er uteksaminert fra det som nå er det 5. årige masterprogrammet i arealplanlegging, eiendomsfag eller geomatikk ved Universitetet for miljø- og biovitenskap (tidligere Norges landbrukshøgskole). ${ }^{*}$... Foreningens medlemmer mottar det vitenskapelige tidsskriftet Kart og Plan og Meldingsbladet *... 
NJKF er med andre ord en organisasjon som gjennom sin medlemsmasse har stor faglig tyngde, og gjennom utgivelsen av det eneste norskspråklige vitenskapelige tidsskriftet på fagområdet vil de utvilsomt oppfylle relevanskravet.

\section{Autorisasjonsordning}

Et fellestrekk for god revisorskikk, god advokatskikk, god regnskapsføringsskikk og god meglerskikk er at disse etikkreglene er knyttet til yrker med ulike autorisasjonsordninger. Disse ordningene regulerer hovedsakelig privat tjenesteproduksjon. Dette var også modellen som lå til grunn for forslagene i NOU (1999: 1). Her var det særlig forslagene om å innføre et kompetansekrav til landmålerne, samt at oppmålingsforretningene skulle defineres som en tjenesteproduksjon, som var kontroversielle. I Ot.prp. nr. 57 (2006-2007) ble derimot ikke disse lovforslagene videreført, og landmålerne er derfor ikke underlagt en autorisasjonsordning.

Ut fra et yrkesetisk perspektiv er ikke dette av avgjørende betydning. Det yrkesetiske perspektivet vil i seg selv ha elementer av både rettslige og ikke-rettslige reaksjoner overfor dem som bryter de yrkesetiske reglene. Ikke-rettslige reaksjoner i form av sosiale sanksjoner og fordømmelser, kan i visse tilfeller være svært effektive.

Når det gjelder de rettslige reaksjonene kan derimot autorisasjonsordninger være av avgjørende betydning. Vanligvis vil det være ulike rettslige reaksjoner og sanksjoner knyttet til brudd på de yrkesetiske reglene. De milde reaksjonsformene er for eksempel kritikk fra et tilsynsorgan eller advarsel fra autorisasjonsnemnd/-myndighet, mens de mer alvorlige sanksjonsformene kan være bøter og straff $\mathrm{i}$ form av fengsel når dette kan knyttes til økonomisk utroskap. I denne sammenheng vil inndragning av autorisasjon kunne være det mest alvorlige for enkelte. For selvstendig næringsdrivende advokater, revisorer, regnskapsførere eller eiendomsmeglere vil inndragning av autorisasjon for en periode på to år sannsynligvis innebære at virksomheten må legges ned, ettersom det kan være vanskelig for andre å overta hele kundeporteføljen. I tillegg vil en i denne perioden ha et yrkesforbud. Det finnes ikke en tilsvarende obligatorisk autorisasjonsordning for landmålere, noe som dermed begrenser de juridiske reaksjonsformene. Tilsynsorganet for de kommunale oppmålingsmyndighetene er Statens kartverk, og reaksjonsformene de kan anvende, er hovedsakelig kritikk og pålegg om retting av feil og mangler etter matrikkelloven $₫ 28$.

Det at god landmålerskikk er knyttet til oppmålingsforretninger, som er en offentlig myndighetsutøvelse, er en vesentlig forskjell fra de utvalgte SGS-reglene, som hovedsakelig er knyttet til privat tjenesteproduksjon. Oppmerksomheten og synet på etiske problemstillinger vil selvfølgelig variere mellom yrker, men det vil også variere mellom utøverne i de ulike yrkene. Oppmålingsforretningen som gjennomføres av landmåleren, er finansiert gjennom gebyrer. Gebyrmalene er utarbeidet med utgangspunkt i en standard for faktiske kostnader. I de enkelttilfellene hvor det er gjort vedtak om gebyr som klart avviker fra de faktiske kostnadene, kan vedtaket bli kjent ugyldig, slik som i dommen fra Rt. 2004 s. 1603. I lys av dette er det ikke noen grunn til at offentlig myndighetsutøvelse og privat tjenesteproduksjon isolert sett skulle tilsi ulike etiske perspektiv. 


\section{Hypotesen}

I de opprinnelig etiske retningslinjene fremgikk profesjonsansvaret av $\$ 1$, som fremhevet at landmåler «skal bidra til et seriøst og godt omdømme for profesjonen». Når det gjaldt faglig integritet, var det i $₫ 3$ opplistet fem punkter som dekket både generelle og spesielle forhold. Flere av disse punktene inngikk i de øvrige elementene. Objektivitet var ett av de punktene i $\$ 3 \mathrm{nr}$. 4: Landmålere skal «unngå forhold som kan påvirke egen objektivitet i relasjon til oppdragsgivere, leverandører, eller parter i saker kandidaten arbeider med».

Taushetsplikten fremgikk av $₫ 5$, og var knyttet til opplysninger av personlig og privat karakter som en blir kjent med gjennom sitt virke. Som følge av at matrikkelloven ble endret slik at oppmålingsforretningen fortsatt skal være myndighetsutøvelse, vil forvaltningsloven $₫ 13$ og de etterfølgende paragrafene gjelde. Paragrafen hadde dermed liten selvstendig betydning, ettersom den verken var dekkende for taushetsplikten eller ga et mer nyansert bilde av den.

Kompetansekrav var et annet element som var dekket gjennom punktene i $\$ 3 \mathrm{nr}$. 1 . Med manglende krav til kompetanse gjennom lov og forskrifter var det svært viktig at det prinsipielt var fastslått at landmåler skal «ajourføre og videreutvikle egen kompetanse for å sikre kvalitet på eget arbeid».

Ved revisjonen av de yrkesetiske reglene i 2011 ble reglene forenklet til Yrkesetikk med følgende inndeling: ${ }^{12}$

- Profesjonsansvar

- Faglig oppdatering

- Integritet

- Objektivitet

- Taushetsplikt

Både de opprinnelige etiske reglene og de forenklede reglene til Yrkesetikk inneholder altså de fem elementene.

\section{En samlet analyse av den rettslige betydningen}

Formålet med denne artikkelen har vært å vise den rettslige betydningen av de lovfestede SGS-reglene. I tillegg er de utvalgte SGS-reglene sammenlignet ut fra hjemmel og bransjeorganisasjon, autorisasjonsordning og en hypotese om fem elementer: 
Tabell 1: Oppsummering

\begin{tabular}{|l|l|l|l|l|l|}
\hline & $\begin{array}{l}\text { God } \\
\text { revisorskikk }\end{array}$ & $\begin{array}{l}\text { God } \\
\text { advokatskikk }\end{array}$ & $\begin{array}{l}\text { God } \\
\text { regnskaps- } \\
\text { føringsskikk }\end{array}$ & $\begin{array}{l}\text { God } \\
\text { meglerskikk }\end{array}$ & $\begin{array}{l}\text { God } \\
\text { landmåler- } \\
\text { skikk }\end{array}$ \\
\hline Hjemmel & $\begin{array}{l}\text { Revisorloven } \\
\S 4-1, \text { jf. } \S 5-2\end{array}$ & $\begin{array}{l}\text { Domstolloven } \\
\S 224, \text { jf. advo- } \\
\text { katforskriften }\end{array}$ & $\begin{array}{l}\text { Regnskaps- } \\
\text { førerloven } \S 2\end{array}$ & $\begin{array}{l}\text { Eiendoms- } \\
\text { meglerloven } \S \\
6-3\end{array}$ & $\begin{array}{l}\text { Matrikkel- } \\
\text { loven } \\
\S 33\end{array}$ \\
\hline $\begin{array}{l}\text { Organisa- } \\
\text { sjon }\end{array}$ & DnR & DNA & NARF & NEF & NJKF \\
\hline Autorisasjon & $\begin{array}{l}\text { Finanstil- } \\
\text { synet }\end{array}$ & $\begin{array}{l}\text { Tilsynsrådet } \\
\text { for advokat- } \\
\text { virksomhet }\end{array}$ & Finanstilsynet & Finanstilsynet & Nei \\
\hline $\begin{array}{l}\text { De fem } \\
\text { elementene }\end{array}$ & Ja & Ja & Ja & Nei & Ja \\
\hline
\end{tabular}

Særtrekkene for de ulike yrkesetiske reglene fremgår av tabell 1 ovenfor. Analysen viser at den nå lovfestede SGS-regelen «god landmålerskikk» har de samme fem elementene som en finner i både god revisorskikk, god advokatskikk og god regnskapsføringsskikk. Variasjonen i utvalget viser seg ved at de etiske reglene fra NEF er svært forskjellige fra de andre reglene som er analysert. Når det gjelder de øvrige forhold som er fremhevet her, så danner de på mange måter rammen for de yrkesetiske reglene. God landmålerskikk har mye til felles med de øvrige reglene, det er kun forskjellen i autorisasjonsordning som er vesentlig.

Med unntak av god advokatskikk, hvor Tilsynsrådet for advokatvirksomhet har ansvaret for å føre tilsyn med advokatbevillingene, er det Finanstilsynet som har ansvaret for autorisasjonsordningene. Ellers er det verdt å legge merke til at det kun er god advokatskikk som har fastsatt de yrkesetiske reglene gjennom forskrift. Forklaringen på hvorfor god meglerskikk ikke inneholder de fem elementene, kan være den passive opptredenen fra NEF som har ført til lovgiver har tatt ansvar for utviklingen her.

Analysen i denne artikkelen har vist at de yrkesetiske reglene har en viss rettslig betydning, selv om den varierer. For yrker med autorisasjonsordning vil det å miste bevilling/ tillatelse/autorisasjon ofte være den sterkeste sanksjonsformen, ettersom det vil innebære et yrkesforbud for kortere eller lengre tid. Sosial fordømmelse vil også være en sterk sanksjonsform, siden det vil kunne være av avgjørende betydning for fremtidig yrkesutøvelse. Eventuelle erstatningskrav kan derfor fremstå som en langt svakere sanksjonsform overfor yrkesutøveren. Ved mindre beløp har det liten betydning, og ved større beløp blir det delvis dekket gjennom forsikringsordninger.

Ettersom oppmålingsforretningen er underlagt et kommunalt monopol, utført av landmålere som ikke er underlagt en autorisasjonsordning, vil de etiske retningslinjene ikke ha betydning verken for kommunens eller for landmålerens rett til å avholde oppmålingsforretninger. De etiske retningslinjene vil derfor primært være av betydning for eventuelle erstatningskrav. Det er likevel ikke tvil om at medieomtale av avvik fra de etiske retningslinjene kan påvirke fremtidig praksis. 
De lovfestede SGS-reglene har tidligere hatt det til felles at de er knyttet til offentlige autorisasjonsordninger i det som hovedsakelig har vært privat tjenesteyting. Med innføringen av god landmålerskikk er dette endret slik at offentlig tjenesteyting uten autorisasjonsordning nå har blitt den første lovfestede SGS-regelen. Det kan åpne opp for at ulovfestede SGS-regler med autorisasjonsordning som hovedsakelig har vært knyttet til privat tjenesteyting (som f.eks. leger og annet helsepersonell), kan bli lovfestet. Videre åpner det opp for at ulovfestede SGS-regler uten autorisasjonsordning som hovedsakelig har vært knyttet til privat tjenesteyting (som f.eks. ingeniører), kan bli lovfestet.

Ved å kodifisere slike ulovfestede SGS-regler vil de yrkesetiske reglene utvilsomt få en langt større rettslig betydning, slik at domstolene i større grad enn i dag må realitetsbehandle brudd på konkrete yrkesetiske regler.

\section{Noter}

1 Lov 17. juni $2005 \mathrm{nr} .101$ om eigedomsregistrering (matrikkellova).

2 I denne artikkelen avgrenses det mot en nærmere drøftelse av profesjonsbegrepet.

3 Lov 17. juni $2005 \mathrm{nr} .90$ om mekling og rettergang i sivile tvister (tvisteloven).

4 Lov 15. januar $1999 \mathrm{nr} .2$ om revisjon og revisorer(revisorloven).

5 Lov 13. august $1915 \mathrm{nr} .6$ om domstolene (domstolloven).

6 Forskrift til domstolloven kapittel 11 (advokatforskriften).

7 Ettersom Michelsen (1999) ikke har drøftet selvdømmeordningen i forbindelse med god advokatskikk, fremstår denne henvisningen som noe underlig. Det endrer derimot ikke det prinsipielle utgangspunktet om at domstolene har en slik kompetanse.

8 Lov 18. juni $1993 \mathrm{nr} .109$ om autorisasjon av regnskapsførere. FOR 1999-02-08 nr. 196: Forskrift om autorisasjon av regnskapsførere m.v.

10 Lov 29. juni $2007 \mathrm{nr} .73$ om eiendomsmegling.

11 Lov 16. juni $1989 \mathrm{nr} .53$ om eiendomsmegling.

12 På bakgrunnen av arbeidet med denne artikkelen ble jeg invitert med som en del av arbeidsgruppen som reviderte og forenklet reglene for yrkesetikk.

\section{Litteratur}

Andenæs, J. (1998) Statsforfatningen i Norge. Oslo: Tano Aschehoug.

Bergsåker, T. (2008) Eiendomsmegling - omsorgsplikt og god meglerskikk. Med et spesialstudium av salg ved budgivningskonkurranse. Doktorgrad ved Universitetet i Oslo.

Boe, E. (1996) Innføring i juss. Oslo: Tano Aschehoug.

Eckhoff, T. \& Helgesen, J.E. (1997) Rettskildelore. Oslo: Tano Aschehoug.

Fleicher, C.A. (1998) Rettskilder og juridisk metode. Oslo: Ad Notam Gyldendal.

Gomard, B. (1997) Samarbejde og ansvar i selskaber og koncerner. København: GadJura.

Haraldsen, H.I. (2008) Regler for god advokatskikk med kommentarer. Medarbeidere: M. Eggen, J. Finne, H. Tveit, T. Welde \& O. Wisløf. Oslo: Advokatforeningen.

Ims, K.J. (2001) Etiske retningslinjer - som etisk læringsprosess med forankring i organisasjonens verdigrunnlag. I Festskrift til Erling S. Andersens sekstiårsdag, red. P. Gottschalk, A. WelleStrand \& E.S. Andersen, s. 335-349. Oslo: NKI Forlaget. 
Lunde, T. (2001) God forretningsskikk næringsdrivande imellom. Bergen: Fagbokforlaget.

NOU (1987:14) Eiendomsmegling. Oslo: (utgiver ikke registrert).

NOU (1999:1) Lov om eiendomsregistrering. Oslo: Miljøverndepartementet.

NOU (2002:18) Rett til rett. Oslo: Justis- og beredskapsdepartementet.

Nygaard, N. (2004) Rettsgrunnlag og standpunkt. Oslo: Universitetsforlaget.

Ot.prp. nr. 7 (1990-1991) Om lov om endringer i domstolloven m.m. (advokatlovgivningen m.m). Oslo: Justis- og politidepartementet.

Ot.prp. nr. 39 (1994-1995) Om lov om endringer i domstolloven mm (disiplinor- og tilsynsordninger for advokater). Oslo: Justis- og politidepartementet.

Ot.prp. nr. 70 (2004-2005) Om lov om eigedomsregistrering. Oslo: Miljøverndepartementet.

Ot.prp. nr. 44 (2005-2006) Om lov om endringer i lov 18. juni 1993 nr. 109 om autorisasjon av regnskapsførere (regnskapsfører- loven), lov 15. januar $1999 \mathrm{nr} .2 \mathrm{om}$ revisjon og revisorer (revisorloven), lov 10. juni $1988 \mathrm{nr}$. 40 om finansieringsvirksomhet og finansinstitusjoner (finansieringsvirksomhetsloven) og enkelte andre lover. Oslo: Finansdepartementet.

Ot.prp. nr. 57 (2006-2007) Om lov om endringar i lov 17. juni 2005 nr. 101 om eigedomsregistrering o.a. Oslo: Miljøverndepartementet.

Regnskapslovkomiteen av 1959 (avgitt 5. oktober 1962).

Aadland, B. (2012) En juridisk analyse av de spesielle god skikk-reglene. Det teoretiske grunnlaget for landmålerskikk. Kart og plan, 72 (1), s. 30-47. 